\title{
KEMASAN PAKET WISATA JATILUWIH SIGHTSEEING AND ADVENTURE
}

\author{
Renita Sri Lestari \\ Ni Made Oka Karini \\ I GPB. Sasrawan Mananda \\ Email : renitasrilestari@yahoo.co.id \\ PS. S1 Industri Perjalanan Wisata \\ Fakultas Pariwisata UNUD
}

\begin{abstract}
This study discusses and examines potential identification and package tour in Tabanan regency. Qualitative approaches were applied in this research. The data were collected by using observation techniques, in-depths interviews, and documentation technique. Informant and key informant techniques were used to determine the informantion. This study used descriptive qualitative data analysis techniques with three steps which are data reduction, data display and conclusion drawing.

In this study, showed potential identifications taken place in Alas Kedaton, Jatiluwih, Batukaru Temple, Subak Museum, and Tengkudak Village. The packaging of this package tour with itinerary such as visit the Subak Museum, Tengkudak village adventure, visit Jatiluwih, sightseeing in Batukaru temple, sightseeing in Alas Kedaton and shopping in Krisna oleh-oleh. This package tour was presented in tabulated style, Graphic style as well as the calculation of travel costs.
\end{abstract}

Keywords: The Packaging, Package Tour, Tourist Potential.

\section{PENDAHULUAN}

Bali memiliki banyak potensi dengan daya tarik yang khas yaitu keindahan alam, budaya dan hidup masyarakatnya, yang layak dikunjungi. Banyak potensi yang layak dikemas menjadi paket tur yang menarik bagi wisatawan. Perencanaan paket wisata yang lemah dan adanya faktor apabila semakin seimbangnya antara jasa yang diharapkan (expected service) dengan jasa yang diterima (perceived service) maka semakin baik menjadi landasan untuk mengemas paket wisata yang memuaskan wisata sesuai dengan harapan dan keinginan atau permintaan wisatawan.

Apabila terdapat banyak kendala pada saat penyelenggaraan tour seperti contoh yaitu tidak memperhatikan daya fisik wisatawan yang berumur atau lansia, waktu yang dipakai tidak sesuai dengan kondisi di lapangan, tingkat kejenuhuan wisatawan akibat tidak ada variasi daya tarik wisata serta rute yang tidak sesuai dengan alur perjalanan maka paket tour tidak akan memotivasi wisatawan berkunjung lagi. Berpijak pada hal tersebut maka perlu dikemas paket wisata.

\section{TINJAUAN PUSTAKA}

Potensi wisata diartikan sebagai hal-hal dan keadaan, baik itu berwujud fisik ataupun non fisik yang ada di objek wisata dan menjadi daya tarik antara lain : potensi alam, potensi budaya, dan potensi buatan. (Damarjati, 2001:138)

Package tour sebagai suatu rencana perjalanan wisata yang telah tersusun secara tetap, dengan harga tertentu yang telah termasuk pula biaya-biaya untuk pengangkutan, fasilitas akomodasi atau hotel, serta daya tarik wisata dan atraksi yang telah tercantum dalam acara itu 
seperti yang telah dijelaskan oleh Suyitno (1999:67).

Menurut Damarjati (2001:124), pengertian tour itinerary secara umum adalah suatu daftar dan jadwal acara tours dengan datadata lengkap mengenai hari-hari, tanggal, jam, tempat-tempat, hotel menginap, tempat pemberangkatan, tempat tiba, acara-acara yang disuguhkan, sehingga dalam keseluruhannya akan menggambarkan jadwal pelaksanaan maupun waktu-waktunya daripada keseluruhan acara tours dari awal sampai akhir.

\section{METODE PENELITIAN}

Penelitian ini dilakukan di beberapa daya tarik wisata yang terletak di Kabupaten Tabanan. Dipilihnya daya tarik tersebut sebagai tempat penelitian karena melihat potensi-potensi yang sudah berkembang sesuai dengan alur perjalanan dari paket wisata. Di samping itu, terdapat banyak hal penunjang yang ada di lokasi tersebut seperti akomodasi yang memadai, restaurant dengan menu yang beragam, serta transportasi yang tersedia di lokasi tersebut yang layak untuk dirancang menjadi paket wisata. Variabel yang ada dalam penelitian ini antara lain :

1. Identifikasi Potensi

Potensi yang dimaksud adalah sesuatu yang terdapat di lokasi penelitian yang menjadi nilai tambah atau sisi positif baik secara fisik maupun non fisik yang memiliki keunikan dan daya tarik, berpeluang untuk dikembangkan yang dapat dijadikan sebagai paket wisata, meliputi : Alas Kedaton, Jatiluwih, Pura Batukaru, Museum Subak, dan Adventure Desa Tengkudak.

2. Kemasan paket wisata di Kabupaten Tabanan berupa deskripsi alur perjalanan wisata yang terdiri dari rincian aktivitas wisata serta perincian biaya wisata.

\section{HASIL DAN PEMBAHASAN Identifikasi Potensi Wisata Alas Kedaton}

Alas Kedaton adalah daya tarik wisata yang terkenal akan hutannya yang luas dan asri, monyet-monyetnya yang berjumlah 300 ekor, serta kelelawarnya yang hidup di tempat ini. Alas Kedaton berlokasi di Desa Kukuh, Kecamatan Marga. Luas dari Alas Kedaton adalah 6,5 hektar. Di tempat ini juga terdapat pohon-pohon dan tanaman yang beragam jenisnya yang berada di hutan hujan Alas Kedaton.

\section{Jatiluwih}

Jatiluwih adalah daya tarik wisata yang terkenal dengan ikonnya sawah dengan terasering berundak-undak beserta sistem irigasi tradisoalnya yang dikenal dengan subak. Luas areal Jatiluwih ini sekitar 636 hektar. Daya tarik Jatiluwih terletak di desa Jatiluwih Kecamatan Penebel. Daya tarik wisata ini ramai dikunjungi oleh baik wisatawan nusantara maupun mancanegara. Wisatawan dapat menikmati keindahan alamnya serta hawa yang terbilang sejuk serta terdapat tempat makan untuk menikmati makanan hasil dari tempat ini.

\section{Pura Batukaru}

Daya tarik wisata ini merupakan tempat yang suci di Kabupaten Tabanan, terletak di Desa wongaya Gede Kecamatan Penebel. Pura ini juga merupakan pura air dari sistem subak di kawasan Catur angga Batukaru yang terkenal akan empat belas subaknya. Tempat ini merupakan daerah yang damai dengan pohonpohon tropis yang subur dan suara indah burung mengelilinginya. Ada kolam ikan besar yang terletak di sisi kanan pura induk. Pura Batukaru dikelilingi oleh hutan hujan tropis yang sangat luas dan wisatawan dapat merasakan hawa yang sejuk dan suasana yang sepi. Pura ini terdiri dari bagian dalam, bagian tengah, dan bagian luar. Pura ini adalah tempat yang indah yang terdiri dari banyak bangunan pura dengan suasana yang sejuk menutupi seluruh kuil tersebut. Wisatawan dapat melihat beberapa pelinggih yang unik yang berbeda fungsi dan peran bagi masyarakat yang memuja pura ini.

\section{Museum Subak}

Museum Subak terletak di Desa Sanggulan Kecamatan Kediri. Daya tarik wisata ini merupakan tempat sumber informasi bagi pengenalan sistem irigasi tradisional yang dikenal dengan subak. Di museum ini wisatawan dapat mempelajari dan melihat alat-alat dan benda yang berfungsi untuk mempermudah dari pengolahan lahan pertanian. Di sini juaga merupakan tempat yang tepat untuk mengenal 
sistem subak itu sendiri dengan cara menonton video dan film dari penggarapan sawah oleh petani, sistem pembagian air, serta kegiatan ritual yang dilakukan mulai dari mengolah tanah hingga memanen padi tersebut.

\section{Adventure Di Desa Tengkudak}

Tempat wisata adventure ini berlokasi di desa tengkudak kecamatan Penebel. Wisatawan dapat menaiki Atv Ride yang merupakan kendaraan seperti motor sedangkan Buggy ride merupakan kendaraan yang lebih menyerupai mobil. Rute yang dilalui wisatawan saat mengendarai dua kendaraan ini adalah pemandangan sawah sekitar Desa Tengkudak, serta alam pedesaan yang amsih tradisional yang khas akan suasananya yang jauh dari kebisisngan kota.

\section{Pengemasan Paket Wisata} Paket Wisata Dalam Bentuk Tabel

Paket Wisata 1 Hari (Full Day Tour) "Jatiluwih Sightseeing and Adventure" Itinerary : Museum Subak - Adventure di Desa Tengkudak Jatiluwih - Batukaru - Alas Kedaton - Khrisna Oleh-oleh.

\begin{tabular}{lll}
\hline Waktu & Tempat & \multicolumn{1}{c}{ Itinerary } \\
\hline 07.30 & Denpasar & Meeting service di Puri Ayu hotel \\
\hline 07.45 & Denpasar & $\begin{array}{l}\text { Meninggalkan hotel menuju ke Museum Subak Bali, untuk melihat museum } \\
\text { khusus pertanian di Bali }\end{array}$ \\
\hline 09.15 & $\begin{array}{l}\text { Desa } \\
\text { Sanggulan }\end{array}$ & $\begin{array}{l}\text { Sampai di Museum Subak Bali, wisatawan diajak melihat alat dan benda } \\
\text { yang dipergunakan untuk mebantu penggarapan lahan pertanian }\end{array}$ \\
\hline 10.15 & $\begin{array}{l}\text { Desa } \\
\text { Sanggulan }\end{array}$ & $\begin{array}{l}\text { Meninggalkan Museum Subak menuju ke ke tempat wisata adventure off } \\
\text { road di desa Tengkudak. }\end{array}$ \\
\hline 11.00 & $\begin{array}{l}\text { Desa } \\
\text { Tengkudak }\end{array}$ & $\begin{array}{l}\text { Sampai di wisata adventure off road di desa Tengkudak, wisatawan dapat } \\
\text { berpetualangan menggunakan ATV ride atau Buggy Ride }\end{array}$ \\
\hline 12.00 & $\begin{array}{l}\text { Desa } \\
\text { Tengkudak }\end{array}$ & $\begin{array}{l}\text { Meninggalkan wisata adventure off road desa Tengkudak menuju ke Desa } \\
\text { jatiluwih }\end{array}$
\end{tabular}

\begin{tabular}{lll}
\hline 12.45 & $\begin{array}{l}\text { Desa } \\
\text { Jatiluwih }\end{array}$ & $\begin{array}{l}\text { Sampai di di objek wisata Jatiluwih wisatawan dapat melihat panorama } \\
\text { hamparan sawah yang berundak-undak }\end{array}$ \\
\hline 14.15 & $\begin{array}{l}\text { Desa } \\
\text { Jatiluwih }\end{array}$ & Meninggalkan desa Jatiluwih menuju ke kawasan Batukaru \\
\hline 14.45 & $\begin{array}{l}\text { Desa } \\
\text { Wongaya } \\
\text { Gede }\end{array}$ & $\begin{array}{l}\text { Sampai di kawasan Batukaru, wisatawan dapat menikmati suasana hutan dan } \\
\text { pura Batukaru }\end{array}$ \\
\hline 15.45 & $\begin{array}{l}\text { Desa } \\
\text { Wongaya } \\
\text { Gede }\end{array}$ & Meninggalkan kawasan Batukaru menuju ke Alas Kedaton \\
\hline 16.30 & Desa Kukuh & $\begin{array}{l}\text { Sampai Alas Kedaton wisatawan dapat melihat aktivitas monyet, dan } \\
\text { kelelawar yang merupakan habitat asli dari Alas Kedaton juga dapat melihat } \\
\text { Pura Alas Kedaton yang memiliki keunikan tersendiri. }\end{array}$ \\
\hline 18.00 & Desa Kukuh & $\begin{array}{l}\text { Meninggalkan Alas Kedaton kembali ke Denpasar menuju ke Khrisna Oleh- } \\
\text { oleh }\end{array}$ \\
\hline 17.45 & Denpasar & $\begin{array}{l}\text { Sampai di pusat perbelanjaan oleh-oleh khas Bali. Khrisna Oleh-oleh ini } \\
\text { menjual segala macam oleh-oleh khas Bali }\end{array}$ \\
\hline 19.15 & Denpasar & Meninggkalkan Khrisna oleh-oleh menuju ke hotel Puri Ayu \\
\hline
\end{tabular}


Vol. 2 No. 2, 2014

\section{Perencanaan Biaya Wisata}

Nama Tour : Jatiluwih Sightseeing and Adventure

Jumlah Peserta : minimal 12 orang

\begin{tabular}{|c|c|c|c|}
\hline No & Uraian & Fixed Cost & Variable Cost \\
\hline 1. & Sewa Mobil & 500.000 & \\
\hline 2. & Tip Pengemudi & 30.000 & \\
\hline 3. & $\begin{array}{l}\text { Tiket Masuk : } \\
\text { - Museum Subak } \\
\text { - Jatiluwih } \\
\text { - Pura Batukaru } \\
\text { - Alas Kedaton } \\
\text { - Adventure di desa Tengkudak }\end{array}$ & & $\begin{array}{c}10.000 \\
10.000 \\
10.000 \\
10.000 \\
500.000\end{array}$ \\
\hline 4. & $\begin{array}{l}\text { Ongkos Parkir } \\
\text { - Museum Subak } \\
\text { - Jatiluwih } \\
\text { - Pura Batukaru } \\
\text { - Alas Kedaton } \\
\text { - Adventure di desa Tengkudak } \\
\text { - Khrisna Oleh-oleh } \\
\end{array}$ & $\begin{array}{l}5.000 \\
5.000 \\
5.000 \\
5.000 \\
5.000 \\
5.000\end{array}$ & \\
\hline 5. & Lunch & & 35.000 \\
\hline 6. & Hotel & & 225.000 \\
\hline 7. & Guide Fee & 150.000 & \\
\hline 8. & Refreshment & & 5.000 \\
\hline 9. & Biaya Administrasi & 100.000 & \\
\hline 10. & Biaya Lain-lain & 50.000 & \\
\hline & Jumlah Biaya & 860.000 & 805.000 \\
\hline & $\begin{array}{l}\text { Biaya Perpeserta } \\
(\mathrm{TCP}=\mathrm{TFC} / \mathrm{n}+\mathrm{TVC})= \\
860.000 / 11+805.000\end{array}$ & & 883.181 \\
\hline & Surcharge $25 \%(25 / 100 \times 883.181)$ & & 220.795 \\
\hline & Harga Peserta & & 1.103 .976 \\
\hline & Konversi(1US\$=9100) & & $\$ 121$ \\
\hline
\end{tabular}

\section{SIMPULAN}

Objek wisata yang berada di Kabupaten Tabanan, yang pertama adalah Alas Kedaton yaitu sebuah Daya tarik wisata yang terkenal akan monyet-monyetnya serta kelelawarnya. Potensi wisata kedua adalah Pura Batukaru yaitu pura yang terletak di tengah hutan hujan dan di bawah gunung Batukaru. Potensi wisata ketiga adalah Museum Subak yaitu sebuah daya tarik wisata yang merupakan tempat untuk mendapatkan informasi dari sistem subak. Potensi wisata keempat adalah Adventure Di Desa Tengkudak yaitu tempat wisata adventure yang berlokasi di desa tengkudak dengan menaiki $A T V$ ride atau Buggy ride dengan rute melewati hamparan terasering sawah dan alam pedesaan.

\section{DAFTAR PUSTAKA}

Paramata, Indriani, dkk. 2013. Perencanaan Paket Wisata Kota Manado. jurnal Planning for Urban Regional and Environment, Volume 2. (http://jpurepwk.ub.ac.id/ article_jurnal /04_Indriani\%\&.indeks.view/008929118 45 diakses pada 15 Maret 2013, pukul 12.56) 
Jurnal IPTA

ISSN : 2338-8633

Vol. 2 No. 2, 2014

Damarjati, R.S. 2001. Istilah-istilah Dunia Pariwisata. Jakarta : PT. Pradnya Paramita

Suwantoro, Gamal. 1997. Dasar-dasar Pariwisata. Yogyakarta: ANDI

Suyitno, 2001. Perencanaan Wisata, Yogyakarta : Kanisius. 1999. Perencanaan Wisata, Yogyakarta : Kanisius. 